\title{
Penggunaan Sistem Pendukung Keputusan Seleksi Atlet Silat Sekotawaringin Timur Menggunakan Metode Simple Additive Weighting
}

\author{
Norman, Rosida, Shinta Putri, Nurahman \\ Fakultas Ilmu Komputer, Program Studi Sistem Informasi, Universitas Darwan Ali, Indonesia \\ Email: ${ }^{1}$ norman.478@gmail.com, ${ }^{2}$ rosidaida1949@gmail.com, ${ }^{3}$ shintaputri3579@gmail.com
}

\begin{abstract}
Abstrak-Penelitian ini membahas sebuah kasus yang ingin dituntaskan dengan menggunakan metode SAW (Simple Additive Weighting). Beberapa orang sering bingung dan kebingungan, bagaimana cara untuk melakukan penyelesaian permasalahan sebuah kasus dengan menggunakan metode yang sudah diterapkan. Pada dasarnya semua permasalahan maupun semua kasus yang ingin dipecahkan atau ingin kita cari sistem pengambilan keputusannya itu cukup dengan beberapa metode yang ingin kita lakukan. Disini metode yang digunakan adalah metode SAW, metode SAW ini sangat mudah untuk dipahami dan untuk di gunakan dalam berbagai suatu kasus. Salah satu contohnya yang dibahas disini adalah kasus mencari seleksi atlet silat sekotawaringin timur dari 1 sampai 100 orang ini akan dites dan dinilai dari alternatif yang ditentukan, sampai pada akhirnya mencari dan menemukan mana juara 1 dari 100 orang tersebut yang mendapatkan rengking yang terbaik.
\end{abstract}

Kata Kunci: Seleksi, Atlet, Silat

Abstract-This study discusses a case that wants to be completed using the SAW (Simple Additive Weighting) method. Some people are often confused and confused, how to solve the problem of a case using methods that have been applied. Basically all the problems and all the cases that we want to solve or want to find the decision-making system are enough with some methods that we want to do. Here the method used is the SAW method, the SAW method is very easy to understand and to be used in various cases. One of the examples discussed here is the case of searching for a selection of silat athletes from East Sekotawaringin East from 1 to 100 people will be tested and judged from the determined alternatives, until in the end searching and finding which champion 1 of 100 people who get the best rank.

Keywords: Silat, Athlete, Selection

\section{PENDAHULUAN}

Kebanyakan dari metode-metode diberbagai pemecahan masalah sudah menjadi yang dianggap sangat penting bagi masyarakat, mahasiswa, mahasiswi, ataupun bagi para pemecah masalah dibelahan dunia dimanapun mereka berada. Kehadiran SPK (Sistem Pengambilan Keputusan) di masyarakat bukanlah hal-hal yang baru didengar, dan hampir semua kalangan mengetahui dan mempelajari metode-metode yang diterapkan di SPK tersebut, salah satu metode yang digunakan adalah SAW (Simple Additive Weighting). Berbagai cara maupun metode dikembangkan dan dirancang sedemikian rupa bagusnya dalam mengatasi dan dapat membantu menentukan suatu permasalahan yang ingin dipecahkan, sehingga solusinya pun dapat diselesaikan[1].

Semakin banyaknya metode-metode yang ada di SPK ini, dari metode Naïve bayes, AHP, DSS, C45, Fuzzy, dan SAW merupakan menjadi pertimbangan bagi seseorang yang ingin menemukan keputusan. Sehingga pada dasarnya balik lagi pada sipemahan metode tersebut, mana metode yang ingin orang tersebut pilih dan yang paling dia kuasai agar menjadi solusi dalam melakukan pengambilan keputusannya. Dan oleh karena itulah biasanya memerlukan cara mana yang lebih epektif dan kreatif untuk melakukan peninjauan dalam metode yang digunakan dari metode tersebut. Pada suatu kasus ini menggunakan metode SAW, mengapa demikian. Karena dalam metode SAW ini kita dapat dengan mudah dalam melakukan perhitungan ataupun dalam melakukan perengkingan yang sudah ditentukan dari sipihak penilai dalam seleksi atlet silat tersebut. Beberapa dari aspek penilaian tersebut yang diajukan sebagai seleksi terhadap atlet silat diantaranya umur, sabuk, kedisiplinan, kekuatan fisik, kekuatan pukulan, kekuatan tendangan, dan kecepatan. Pihak pelaksana dalam seleksi atlet silat juga menentukan sabuk dari 1 sampai 6 (putih, kuning, hijau, biru, coklat, dan hitam) dan terhitung dari 40, 5, 5, 15, 10, 10, 15 yang berjumlah 1 sampai 100 orang yang akan diseleksi peringkatnya menggunakan metode SAW dalam mengetahui peringkat tersebut[2].

Dalam penelitian ini, metode SAW yang ditentukan menjadi langkah awal untuk melakukan perhitungan dan selanjutnya dapat dietahui dari proses perhitungan tersebut. Adanya permasalahan atau pada suatu kasus yang terjadi, berpengaruh terhadap kesalahan dalam melakukan penilain dan perengkingan. Dan oleh sebab itulah metode SAW merupakan metode yang sangat mudah dalam melakukan perhitungan. Namun belum ada penelitian yang meneliti dengan mengenai hal diatas. Akan tetapi kami mencoba untuk melakukan sebuah penelitian yang mengenai suatu kasus menyeleksi atlet silat sekotawaringin timur menggunakan metode SAW yang akan kami terapkan[3].

\section{METODE PENELITIAN}

\subsection{Observasi}


Untuk tahap ini penulis mengadakan suatu proses kegiatan penelitian dengan melakukan peninjauan ke lokasi di kecamatan baamang dan ketapang secara langsung untuk mencari dan serta mengumpulkan data-data yang ingin menentukan atlet silat mana yang pantas mendapatkan juara 1 atau perengkingan yang pertama dari sekian banyak nya orang yang ikut serta dalam melakukan perebutan gelar juara tersebut[4].

\subsection{Wawancara}

Untuk kesempatan saat itu penulis bertemu secara langsung dengan pihak penyelenggara mencari atlet silat sekotawaringin timur untuk melakukan sesi tanya jawab mengenai hal-hal yang bisa bermanfaat untuk penyelesaian pada tahap proses perhitungan yang akan di lakukan dengan menggunakan metode yang sudah diterapkan, yaitu dengan menggunakan metode SAW (Simple Additive Weighting)[5].

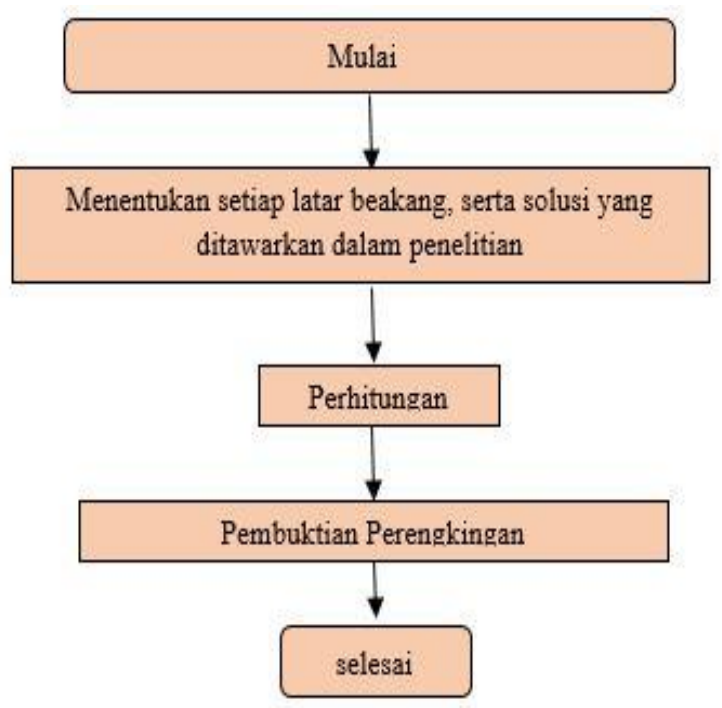

Gambar 1. Metode Penelitian Kasus Seleksi Atlet Silat

Gambar 1 menunjukkan tentang penggambaran umum dalam menggunkan metode SAW untuk melakukan perhitungan yang akan dilakukan penulis. Penjelasannya yang akan diterapkan adalah:

a. Menentukan sebuah topik yang ingin diproses, latar belakang dari permasalahan, dan tujuan dalam melakukan penelitian ini.

b. Studi dari perumusan ini, yang akan dilakuka oleh penulis adalah dengan memperhatikan aspek-aspek yang berlaku dalam melakukan penelitian. Dan juga dalam prosesnya ini, setiap perhitungan akan ditemukan hasil atau bobot dari masing-masing. Sehingga dalam penyeleksiannyapun akan ditemukan, dengan adanya perengkingan serta dapat mengetahui bobot nilai yang tertinggi dari 1 sampai 100 orang tersebut.

\section{HASIL DAN PEMBAHASAN}

Dari poin-poin penjelasan yang sudah dijelaskan sebelumnya, maka penulis mengusulkan sebuah rancangan menggunakan metode SAW yang dilakukan dalam Sistem Pendukung Keputusan (SPK) seleksi atlit silat menggunakan metode Simple Additive Weighting ini[6].

Tabel 1. Penilaian dari si pihak penilai

\begin{tabular}{cllll}
\hline Bobot & Kriteria & & \multicolumn{2}{c}{$\begin{array}{c}\text { Tingkat sabuk } \\
\text { (Rendah ke tinggi) }\end{array}$} \\
\cline { 1 - 2 } 5 & umur & & & \\
\cline { 5 - 6 } 5 & sabuk & kedisiplinan & & Putih \\
15 & kekuatan fisik & & 2 & Kuning \\
& kekuatan & & & \\
10 & pukulan & 3 & Hijau \\
& kekuatan & & & \\
10 & tendangan & 4 & Biru \\
15 & kecepatan & 5 & Coklat \\
& & 6 & Hitam
\end{tabular}

Tabel 1 menunjukan bahwa penelitian ini memiliki model penilaian. Dalam penjelasannya 40 orang sudah masuk dalam umur yang ditentukan, 5 orang sudah masuk dalam sabuk yang ditentukan, 5 orang sudah masuk dalam kedisiplinan yang ditentukan, 15 orang sudah masuk dalam kekuatan fisik yang ditentukan, 10 orang sudah 
masuk dalam kekuatan pukulan yang ditentukan, 10 orang sudah masuk dalam kekuatan tendangan yang ditentukan, 15 orang sudah masuk dalam kecepatan yang ditentukan. Dan sehingga ditotalkan menjadi 100 orang yang akan diseleksi dalam atlet silat. Pada bagian ini berisi analisa, hasil serta pembahasan dari topik penelitian, yang bisa di buat terlebih dahulu metodologi penelitian. Bagian ini juga merepresentasikan penjelasan yang berupa penjelasan, gambar, tabel dan lainnya[7].

Tabel 2. Target dari si pihak penilai

\begin{tabular}{ccccccc}
\hline C1 & C2 & C3 & C4 & C5 & C6 & C7 \\
\hline 0,4 & 0,05 & 0,05 & 0,15 & 0,1 & 0,1 & 0,15 \\
MIN & MAX & MAX & MAX & MAX & MAX & MAX \\
\hline
\end{tabular}

Pada proses ini dalam pencarian pemecahan angkanya dengan menggunakansistem pembagian yang sudah diatur dari sipihak penilai yang akan dilakukan. 40/100=0,4. 5/100=0,5. 5/100=0,5. 15/100=0,15. 10/100=0,1. $10 / 100=0,1 . \quad 15 / 100=0,15$.

Dan MIN untuk (umur)

MAX untuk (sabuk)

MAX untuk (kedisiplinan)

MAX untuk (kekuatan fisik)

MAX untuk (kekuatan pukulan)

MAX untuk (kekuatan tendangan)

MAX untuk (kekuata kecepatan)

Tabel 3. Data Rating Kecocokan

\begin{tabular}{|c|c|c|c|c|c|c|c|c|}
\hline No & Nama & Umur & Sabuk & Kedisiplinan & $\begin{array}{c}\text { Kekuatan } \\
\text { Fisik }\end{array}$ & $\begin{array}{l}\text { Kekuatan } \\
\text { Pukulan }\end{array}$ & $\begin{array}{l}\text { Kekuatan } \\
\text { Tendangan }\end{array}$ & Kecepatan \\
\hline 1 & AZHAR & 10 & 4 & 56 & 80 & 83 & 84 & 78 \\
\hline 2 & NORMAN & 9 & 4 & 85 & 90 & 84 & 84 & 75 \\
\hline 3 & GILANG & 9 & 4 & 80 & 75 & 70 & 70 & 85 \\
\hline 4 & SUSI & 12 & 3 & 80 & 80 & 75 & 60 & 75 \\
\hline 5 & JUMRAT & 8 & 4 & 80 & 70 & 80 & 60 & 75 \\
\hline 6 & JASMAN & 8 & 4 & 70 & 70 & 77 & 74 & 75 \\
\hline 7 & JUDIN & 9 & 3 & 80 & 80 & 60 & 60 & 92 \\
\hline 8 & JUNGUK & 10 & 6 & 77 & 87 & 80 & 80 & 85 \\
\hline 9 & JENG & 10 & 6 & 56 & 80 & 83 & 84 & 78 \\
\hline 10 & OJENG & 9 & 6 & 85 & 90 & 84 & 84 & 75 \\
\hline 11 & OJON & 9 & 6 & 80 & 75 & 70 & 70 & 85 \\
\hline 12 & ONO & 12 & 5 & 80 & 80 & 75 & 60 & 75 \\
\hline 13 & ONOL & 8 & 5 & 80 & 70 & 80 & 60 & 75 \\
\hline 14 & ONAT & 8 & 5 & 70 & 70 & 77 & 74 & 75 \\
\hline 15 & AMUT & 9 & 5 & 80 & 80 & 60 & 60 & 92 \\
\hline 16 & AMI & 10 & 3 & 77 & 87 & 80 & 80 & 85 \\
\hline 17 & ANAM & 10 & 3 & 56 & 80 & 83 & 84 & 78 \\
\hline 18 & ANI & 9 & 3 & 85 & 90 & 84 & 84 & 75 \\
\hline 19 & ULIL & 9 & 6 & 80 & 75 & 70 & 70 & 85 \\
\hline 20 & ALBAB & 12 & 4 & 80 & 80 & 75 & 60 & 75 \\
\hline 21 & ABAS & 8 & 4 & 80 & 70 & 80 & 60 & 75 \\
\hline 22 & AMIN & 8 & 4 & 70 & 70 & 77 & 74 & 75 \\
\hline 23 & RAIS & 9 & 3 & 80 & 80 & 60 & 60 & 92 \\
\hline 24 & JAI & 10 & 4 & 77 & 87 & 80 & 80 & 85 \\
\hline 25 & LANI & 10 & 4 & 56 & 80 & 83 & 84 & 78 \\
\hline 26 & RUSDI & 9 & 3 & 85 & 90 & 84 & 84 & 75 \\
\hline 27 & YANA & 9 & 6 & 80 & 75 & 70 & 70 & 85 \\
\hline 28 & TOMI & 12 & 6 & 80 & 80 & 75 & 60 & 75 \\
\hline 29 & YANTO & 8 & 6 & 80 & 70 & 80 & 60 & 75 \\
\hline 30 & YANTI & 8 & 6 & 70 & 70 & 77 & 74 & 75 \\
\hline 31 & YANUR & 9 & 5 & 80 & 80 & 60 & 60 & 92 \\
\hline 32 & YAMIN & 10 & 5 & 77 & 87 & 80 & 80 & 85 \\
\hline 33 & RAMLI & 10 & 5 & 56 & 80 & 83 & 84 & 78 \\
\hline 34 & AMAH & 9 & 5 & 85 & 90 & 84 & 84 & 75 \\
\hline 35 & RUSNI & 9 & 3 & 80 & 75 & 70 & 70 & 85 \\
\hline 36 & RUSTAN & 12 & 3 & 80 & 80 & 75 & 60 & 75 \\
\hline
\end{tabular}




\begin{tabular}{|c|c|c|c|c|c|c|c|c|}
\hline 37 & RUSMAN & 8 & 3 & 80 & 70 & 80 & 60 & 75 \\
\hline 38 & ANANG & 8 & 6 & 70 & 70 & 77 & 74 & 75 \\
\hline 39 & ALUH & 9 & 4 & 80 & 80 & 60 & 60 & 92 \\
\hline 40 & IJUL & 10 & 4 & 77 & 87 & 80 & 80 & 85 \\
\hline 41 & JUNAI & 10 & 4 & 56 & 80 & 83 & 84 & 78 \\
\hline 42 & ANWAR & 9 & 3 & 85 & 90 & 84 & 84 & 75 \\
\hline 43 & BANI & 9 & 4 & 80 & 75 & 70 & 70 & 85 \\
\hline 44 & CANDI & 12 & 4 & 80 & 80 & 75 & 60 & 75 \\
\hline 45 & DONO & 8 & 3 & 80 & 70 & 80 & 60 & 75 \\
\hline 46 & EDANG & 8 & 6 & 70 & 70 & 77 & 74 & 75 \\
\hline 47 & RIAN & 9 & 6 & 80 & 80 & 60 & 60 & 92 \\
\hline 48 & GILANG & 10 & 6 & 77 & 87 & 80 & 80 & 85 \\
\hline 49 & SIDUN & 10 & 6 & 56 & 80 & 83 & 84 & 78 \\
\hline 50 & HILDA & 9 & 5 & 85 & 90 & 84 & 84 & 75 \\
\hline 51 & GANDI & 9 & 5 & 80 & 75 & 70 & 70 & 85 \\
\hline 52 & YUKA & 12 & 5 & 80 & 80 & 75 & 60 & 75 \\
\hline 53 & YONIF & 8 & 5 & 80 & 70 & 80 & 60 & 75 \\
\hline 54 & HISNA & 8 & 3 & 70 & 70 & 77 & 74 & 75 \\
\hline 55 & GANDEN & 9 & 3 & 80 & 80 & 60 & 60 & 92 \\
\hline 56 & GONAH & 10 & 3 & 77 & 87 & 80 & 80 & 85 \\
\hline 57 & RUDIN & 10 & 6 & 56 & 80 & 83 & 84 & 78 \\
\hline 58 & JONI & 9 & 4 & 85 & 90 & 84 & 84 & 75 \\
\hline 59 & YANA & 9 & 4 & 80 & 75 & 70 & 70 & 85 \\
\hline 60 & KANI & 12 & 4 & 80 & 80 & 75 & 60 & 75 \\
\hline 61 & JOHAN & 8 & 3 & 80 & 70 & 80 & 60 & 75 \\
\hline 62 & DONNI & 8 & 4 & 70 & 70 & 77 & 74 & 75 \\
\hline 63 & NAIDI & 9 & 4 & 80 & 80 & 60 & 60 & 92 \\
\hline 64 & OSMAN & 10 & 3 & 77 & 87 & 80 & 80 & 85 \\
\hline 65 & RINI & 10 & 6 & 56 & 80 & 83 & 84 & 78 \\
\hline 66 & WANDY & 9 & 6 & 85 & 90 & 84 & 84 & 75 \\
\hline 67 & RUSLAN & 9 & 6 & 80 & 75 & 70 & 70 & 85 \\
\hline 68 & AIRAH & 12 & 6 & 80 & 80 & 75 & 60 & 75 \\
\hline 69 & TONO & 8 & 5 & 80 & 70 & 80 & 60 & 75 \\
\hline 70 & JUNIATI & 8 & 5 & 70 & 70 & 77 & 74 & 75 \\
\hline 71 & YUSLI & 9 & 5 & 80 & 80 & 60 & 60 & 92 \\
\hline 72 & IJUL & 10 & 5 & 77 & 87 & 80 & 80 & 85 \\
\hline 73 & FARTO & 10 & 3 & 56 & 80 & 83 & 84 & 78 \\
\hline 74 & GONO & 9 & 3 & 85 & 90 & 84 & 84 & 75 \\
\hline 75 & RESNA & 9 & 3 & 80 & 75 & 70 & 70 & 85 \\
\hline 76 & SINO & 12 & 6 & 80 & 80 & 75 & 60 & 75 \\
\hline 77 & FUAH & 8 & 4 & 80 & 70 & 80 & 60 & 75 \\
\hline 78 & CIMAN & 8 & 4 & 70 & 70 & 77 & 74 & 75 \\
\hline 79 & AKTON & 9 & 4 & 80 & 80 & 60 & 60 & 92 \\
\hline 80 & RISJO & 10 & 3 & 77 & 87 & 80 & 80 & 85 \\
\hline 81 & TINNI & 10 & 4 & 56 & 80 & 83 & 84 & 78 \\
\hline 82 & DIMA & 9 & 4 & 85 & 90 & 84 & 84 & 75 \\
\hline 83 & JOSEN & 9 & 3 & 80 & 75 & 70 & 70 & 85 \\
\hline 84 & YULI & 12 & 6 & 80 & 80 & 75 & 60 & 75 \\
\hline 85 & IMAN & 8 & 6 & 80 & 70 & 80 & 60 & 75 \\
\hline 86 & KUSNIL & 8 & 6 & 70 & 70 & 77 & 74 & 75 \\
\hline 87 & RODIK & 9 & 6 & 80 & 80 & 60 & 60 & 92 \\
\hline 88 & ISMAN & 10 & 5 & 77 & 87 & 80 & 80 & 85 \\
\hline 89 & ANGGA & 10 & 5 & 56 & 80 & 83 & 84 & 78 \\
\hline 90 & HINTAN & 9 & 5 & 85 & 90 & 84 & 84 & 75 \\
\hline 91 & AWAN & 9 & 5 & 80 & 75 & 70 & 70 & 85 \\
\hline 92 & DUSMAN & 12 & 3 & 80 & 80 & 75 & 60 & 75 \\
\hline 93 & ASMIN & 8 & 3 & 80 & 70 & 80 & 60 & 75 \\
\hline 94 & TILAH & 8 & 3 & 70 & 70 & 77 & 74 & 75 \\
\hline 95 & YANTO & 9 & 6 & 80 & 80 & 60 & 60 & 92 \\
\hline 96 & HANI & 10 & 4 & 77 & 87 & 80 & 80 & 85 \\
\hline 97 & RUSMIN & 8 & 4 & 56 & 80 & 83 & 84 & 78 \\
\hline 98 & YUNI & 8 & 4 & 85 & 90 & 84 & 84 & 75 \\
\hline
\end{tabular}




\begin{tabular}{clccccccc}
\hline 99 & SIDIQ & 9 & 3 & 80 & 75 & 70 & 70 & 85 \\
100 & ERLAN & 10 & 4 & 80 & 80 & 75 & 60 & 75 \\
\hline
\end{tabular}

Rumus:

Skor dari rumus 1 dan rumus 2

Untuk perhitungan rumus satu, adalah sebagai berikut:

RUMUS 1

MAX dan MIN

Rumus Max : = DIA dibagi MAX (semua yang ada didalam kreteria)

Rumus Min : = MIN (semua yang ada didalam kreteria DIA) dibagi DIA

Sedangkan untuk rumus dua, adalah sebagai berikut:

RUMUS $2=($ Bobot $*$ hasil normalisasi rumus 1$)+($ bobot $*$ hasil normalisasi rumus 1$)$ sampai seterusnya unalan huruf kecil dan abjed untuk penomoran list.

a. Seting $5 \mathrm{~mm}$ untuk bagian kiri menjorok kedalam.

b. Jika lebih dari 1 level penomoran gunakan penomoran angka untuk list selanjutnya:

1. Gunakan penomoran angka.

2. Selanjutnya

Tabel 4. Hasil Perhitungan

Rumus 1

\begin{tabular}{|r|r|r|r|r|r|r|}
\hline 0,8 & 0,7 & 0,7 & 0,9 & 1 & 1 & 0,8 \\
\hline 0,9 & 0,7 & 1 & 1 & 1 & 1 & 0,8 \\
\hline 0,9 & 0,7 & 0,9 & 0,8 & 0,8 & 0,8 & 0,9 \\
\hline 0,7 & 0,5 & 0,9 & 0,9 & 0,9 & 0,7 & 0,8 \\
\hline 1 & 0,7 & 0,9 & 0,8 & 1 & 0,7 & 0,8 \\
\hline 1 & 0,7 & 0,8 & 0,8 & 0,9 & 0,9 & 0,8 \\
\hline 0,9 & 0,5 & 0,9 & 0,9 & 0,7 & 0,7 & 1 \\
\hline 0,8 & 1 & 0,9 & 1 & 1 & 1 & 0,9 \\
\hline 0,8 & 1 & 0,7 & 0,9 & 1 & 1 & 0,8 \\
\hline 0,9 & 1 & 1 & 1 & 1 & 1 & 0,8 \\
\hline 0,9 & 1 & 0,9 & 0,8 & 0,8 & 0,8 & 0,9 \\
\hline 0,7 & 0,8 & 0,9 & 0,9 & 0,9 & 0,7 & 0,8 \\
\hline 1 & 0,8 & 0,9 & 0,8 & 1 & 0,7 & 0,8 \\
\hline 1 & 0,8 & 0,8 & 0,8 & 0,9 & 0,9 & 0,8 \\
\hline 0,9 & 0,8 & 0,9 & 0,9 & 0,7 & 0,7 & 1 \\
\hline 0,8 & 0,5 & 0,9 & 1 & 1 & 1 & 0,9 \\
\hline 0,8 & 0,5 & 0,7 & 0,9 & 1 & 1 & 0,8 \\
\hline 0,9 & 0,5 & 1 & 1 & 1 & 1 & 0,8 \\
\hline 0,9 & 1 & 0,9 & 0,8 & 0,8 & 0,8 & 0,9 \\
\hline 0,7 & 0,7 & 0,9 & 0,9 & 0,9 & 0,7 & 0,8 \\
\hline 1 & 0,7 & 0,9 & 0,8 & 1 & 0,7 & 0,8 \\
\hline 1 & 0,7 & 0,8 & 0,8 & 0,9 & 0,9 & 0,8 \\
\hline 0,9 & 0,5 & 0,9 & 0,9 & 0,7 & 0,7 & 1 \\
\hline 0,8 & 0,7 & 0,9 & 1 & 1 & 1 & 0,9 \\
\hline 0,8 & 0,7 & 0,7 & 0,9 & 1 & 1 & 0,8 \\
\hline 0,9 & 0,5 & 1 & 1 & 1 & 1 & 0,8 \\
\hline 0,9 & 1 & 0,9 & 0,8 & 0,8 & 0,8 & 0,9 \\
\hline 0,7 & 1 & 0,9 & 0,9 & 0,9 & 0,7 & 0,8 \\
\hline
\end{tabular}

Norman, Copyright (C) 2020, Jurnal JSON, Page 138 


\begin{tabular}{|c|c|c|c|c|c|c|c|}
\hline 1 & 1 & 0,9 & 0,8 & 1 & 0,7 & 0,8 & 0,90 \\
\hline 1 & 1 & 0,8 & 0,8 & 0,9 & 0,9 & 0,8 & 0,91 \\
\hline 0,9 & 0,8 & 0,9 & 0,9 & 0,7 & 0,7 & 1 & 0,87 \\
\hline 0,8 & 0,8 & 0,9 & 1 & 1 & 1 & 0,9 & 0,88 \\
\hline 0,8 & 0,8 & 0,7 & 0,9 & 1 & 1 & 0,8 & 0,85 \\
\hline 0,9 & 0,8 & 1 & 1 & 1 & 1 & 0,8 & 0,92 \\
\hline 0,9 & 0,5 & 0,9 & 0,8 & 0,8 & 0,8 & 0,9 & 0,86 \\
\hline 0,7 & 0,5 & 0,9 & 0,9 & 0,9 & 0,7 & 0,8 & 0,76 \\
\hline 1 & 0,5 & 0,9 & 0,8 & 1 & 0,7 & 0,8 & 0,88 \\
\hline 1 & 1 & 0,8 & 0,8 & 0,9 & 0,9 & 0,8 & 0,91 \\
\hline 0,9 & 0,7 & 0,9 & 0,9 & 0,7 & 0,7 & 1 & 0,86 \\
\hline 0,8 & 0,7 & 0,9 & 1 & 1 & 1 & 0,9 & 0,87 \\
\hline 0,8 & 0,7 & 0,7 & 0,9 & 1 & 1 & 0,8 & 0,85 \\
\hline 0,9 & 0,5 & 1 & 1 & 1 & 1 & 0,8 & 0,90 \\
\hline 0,9 & 0,7 & 0,9 & 0,8 & 0,8 & 0,8 & 0,9 & 0,87 \\
\hline 0,7 & 0,7 & 0,9 & 0,9 & 0,9 & 0,7 & 0,8 & 0,76 \\
\hline 1 & 0,5 & 0,9 & 0,8 & 1 & 0,7 & 0,8 & 0,88 \\
\hline 1 & 1 & 0,8 & 0,8 & 0,9 & 0,9 & 0,8 & 0,91 \\
\hline 0,9 & 1 & 0,9 & 0,9 & 0,7 & 0,7 & 1 & 0,88 \\
\hline 0,8 & 1 & 0,9 & 1 & 1 & 1 & 0,9 & 0,89 \\
\hline 0,8 & 1 & 0,7 & 0,9 & 1 & 1 & 0,8 & 0,86 \\
\hline 0,9 & 0,8 & 1 & 1 & 1 & 1 & 0,8 & 0,92 \\
\hline 0,9 & 0,8 & 0,9 & 0,8 & 0,8 & 0,8 & 0,9 & 0,87 \\
\hline 0,7 & 0,8 & 0,9 & 0,9 & 0,9 & 0,7 & 0,8 & 0,77 \\
\hline 1 & 0,8 & 0,9 & 0,8 & 1 & 0,7 & 0,8 & 0,89 \\
\hline 1 & 0,5 & 0,8 & 0,8 & 0,9 & 0,9 & 0,8 & 0,88 \\
\hline 0,9 & 0,5 & 0,9 & 0,9 & 0,7 & 0,7 & 1 & 0,85 \\
\hline 0,8 & 0,5 & 0,9 & 1 & 1 & 1 & 0,9 & 0,86 \\
\hline 0,8 & 1 & 0,7 & 0,9 & 1 & 1 & 0,8 & 0,86 \\
\hline 0,9 & 0,7 & 1 & 1 & 1 & 1 & 0,8 & 0,91 \\
\hline 0,9 & 0,7 & 0,9 & 0,8 & 0,8 & 0,8 & 0,9 & 0,87 \\
\hline 0,7 & 0,7 & 0,9 & 0,9 & 0,9 & 0,7 & 0,8 & 0,76 \\
\hline 1 & 0,5 & 0,9 & 0,8 & 1 & 0,7 & 0,8 & 0,88 \\
\hline 1 & 0,7 & 0,8 & 0,8 & 0,9 & 0,9 & 0,8 & 0,89 \\
\hline 0,9 & 0,7 & 0,9 & 0,9 & 0,7 & 0,7 & 1 & 0,86 \\
\hline 0,8 & 0,5 & 0,9 & 1 & 1 & 1 & 0,9 & 0,86 \\
\hline 0,8 & 1 & 0,7 & 0,9 & 1 & 1 & 0,8 & 0,86 \\
\hline 0,9 & 1 & 1 & 1 & 1 & 1 & 0,8 & 0,93 \\
\hline 0,9 & 1 & 0,9 & 0,8 & 0,8 & 0,8 & 0,9 & 0,88 \\
\hline 0,7 & 1 & 0,9 & 0,9 & 0,9 & 0,7 & 0,8 & 0,78 \\
\hline 1 & 0,8 & 0,9 & 0,8 & 1 & 0,7 & 0,8 & 0,89 \\
\hline 1 & 0,8 & 0,8 & 0,8 & 0,9 & 0,9 & 0,8 & 0,90 \\
\hline 0,9 & 0,8 & 0,9 & 0,9 & 0,7 & 0,7 & 1 & 0,87 \\
\hline 0,8 & 0,8 & 0,9 & 1 & 1 & 1 & 0,9 & 0,88 \\
\hline 0,8 & 0,5 & 0,7 & 0,9 & 1 & 1 & 0,8 & 0,84 \\
\hline 0,9 & 0,5 & 1 & 1 & 1 & 1 & 0,8 & 0,90 \\
\hline
\end{tabular}

Norman, Copyright (C) 2020, Jurnal JSON, Page 139 


\begin{tabular}{|r|r|r|r|r|r|r|}
0,9 & 0,5 & 0,9 & 0,8 & 0,8 & 0,8 & 0,9 \\
\hline 0,7 & 1 & 0,9 & 0,9 & 0,9 & 0,7 & 0,8 \\
\hline 1 & 0,7 & 0,9 & 0,8 & 1 & 0,7 & 0,8 \\
\hline 1 & 0,7 & 0,8 & 0,8 & 0,9 & 0,9 & 0,8 \\
\hline 0,9 & 0,7 & 0,9 & 0,9 & 0,7 & 0,7 & 1 \\
\hline 0,8 & 0,5 & 0,9 & 1 & 1 & 1 & 0,9 \\
\hline 0,8 & 0,7 & 0,7 & 0,9 & 1 & 1 & 0,8 \\
\hline 0,9 & 0,7 & 1 & 1 & 1 & 1 & 0,8 \\
\hline 0,9 & 0,5 & 0,9 & 0,8 & 0,8 & 0,8 & 0,9 \\
\hline 0,7 & 1 & 0,9 & 0,9 & 0,9 & 0,7 & 0,8 \\
\hline 1 & 1 & 0,9 & 0,8 & 1 & 0,7 & 0,8 \\
\hline 1 & 1 & 0,8 & 0,8 & 0,9 & 0,9 & 0,8 \\
\hline 0,9 & 1 & 0,9 & 0,9 & 0,7 & 0,7 & 1 \\
\hline 0,8 & 0,8 & 0,9 & 1 & 1 & 1 & 0,9 \\
\hline 0,8 & 0,8 & 0,7 & 0,9 & 1 & 1 & 0,8 \\
\hline 0,9 & 0,8 & 1 & 1 & 1 & 1 & 0,8 \\
\hline 0,9 & 0,8 & 0,9 & 0,8 & 0,8 & 0,8 & 0,9 \\
\hline 0,7 & 0,5 & 0,9 & 0,9 & 0,9 & 0,7 & 0,8 \\
\hline 1 & 0,5 & 0,9 & 0,8 & 1 & 0,7 & 0,8 \\
\hline 1 & 0,5 & 0,8 & 0,8 & 0,9 & 0,9 & 0,8 \\
\hline 0,9 & 1 & 0,9 & 0,9 & 0,7 & 0,7 & 1 \\
\hline 0,8 & 0,7 & 0,9 & 1 & 1 & 1 & 1 \\
\hline 1 & 0,7 & 0,7 & 0,9 & 1 & 1 & 0,9 \\
\hline 1 & 0,7 & 1 & 1 & 1 & 1 & 0,9 \\
\hline 0,9 & 0,5 & 0,9 & 0,8 & 0,8 & 0,8 & 1 \\
\hline 0,8 & 0,7 & 0,9 & 0,9 & 0,9 & 0,7 & 1 \\
\hline & & & & & \\
\hline
\end{tabular}

\begin{tabular}{|l|}
\hline 0,86 \\
\hline 0,78 \\
\hline 0,89 \\
\hline 0,89 \\
\hline 0,86 \\
\hline 0,86 \\
\hline 0,85 \\
\hline 0,91 \\
\hline 0,86 \\
\hline 0,78 \\
\hline 0,90 \\
\hline 0,91 \\
\hline 0,88 \\
\hline 0,88 \\
\hline 0,85 \\
\hline 0,92 \\
\hline 0,87 \\
\hline 0,76 \\
\hline 0,88 \\
\hline 0,88 \\
\hline 0,88 \\
\hline 0,88 \\
\hline 0,94 \\
\hline 0,97 \\
\hline 0,87 \\
\hline 0,84 \\
\hline
\end{tabular}

Nomor 98 atas nama Yuni (yang diwarnai hijau muda) adalah peringkat pertama atau perengkingan yang tertinggi dalam penyeleksian atlet silat dari 1 orang sampai 100 orang tersebut, hanya Yuni yang mendapatkan angka yang paling tertinggi dalam perhitungan SAW (Simple Additive Weighting)[8].

Pada tahap ini, proses perhitungan yang pertama kali dihitung pencapaian target yang sudah di tentukan oleh si pihak penyelenggara atlet silat tersebut di hitung dengan penerapan yang disebut seleksi, yang terintegrasi dalam tahap selanjutnya. Setiap seleksi dikembangkan dan diuji untuk pencapaian target yang disebut sebagai seleksi testing. Bertujuan untuk mencari, menempatkan, memperoleh nilai yang tinggi, dan serta mencari perengkingan juara 1 dari sekian banyak nya orang tersebut[9].

\section{KESIMPULAN}

Dari hasil proses perhitungan pada sistem pendukung keputusan menggunakan metode SAW (Simple Additive Weighting) ini, penentuan perengkingan yang dilakukan untuk menentukan seleksi atlet silat sekotawaringin timur sebagai berikut[10]:

1. Sistem pendukung keputusan yang dibuat dapat digunakan untuk membantu menentukan atlet-atlet silat yang memenuhi target mendapatkan juara 1.

2. Dengan menerapkan metode SAW maka dapat membantu pihak penyelenggara dalam proses seleksi atlet silat.

3. Penentuan kriteria seleksi atlet silat untuk para atlet-atlet ditentukan dari umur, sabuk, kedisiplinan, kekuatan fisik, kekuatan pukulan, kekuatan tendangan, dan kecepatan.

4. Telah di temukan juara 1 dari 100 orang yang ikut dalam seleksi atlet silat tersebut, yang dapat membantu bagian penyeleksi atlet silat untuk menentukan juara atlet yang sesuai dengan kriteria yang ada.

5. Perhitungan yang dilakukan dapat mempermudah dan mempercepat proses penyeleksian atlet silat serta dapat mengurangi kesalahan-kesalahan dalam menentukan juara 1 dari sekian banyaknya orang yang ikut seleksi atlet silat[9]. 


\section{REFERENCES}

[1] R. Helilintar, W. W. Winarno, and H. A. Fatta, "Penerapan Metode SAW dan Fuzzy Dalam Sistem Pendukung Keputusan Penerimaan Beasiswa," citec, vol. 3, no. 2, p. 89, Sep. 2016.

[2] A. Setiadi, Y. Yunita, and A. R. Ningsih, "Penerapan Metode Simple Additive Weighting(SAW) Untuk Pemilihan Siswa Terbaik," SISFOKOM, vol. 7, no. 2, p. 104, Sep. 2018

[3] F. Sonata and J. I. M. No, "IMPLEMENTASI METODE SIMPLE ADDITIVE WEIGHTING (SAW) DENGAN PROSES FUZZIFIKASI DALAM PENILAIAN KINERJA DOSEN," vol. 5, p. 10, 2016.

[4] I. G. B. Subawa, I. M. A. Wirawan, and I. M. G. Sunarya, "PENGEMBANGAN SISTEM PENDUKUNG KEPUTUSAN PEMILIHAN PEGAWAI TERBAIK MENGGUNAKAN METODE SIMPLE ADDITIVE WEIGHTING (SAW) DI PT TIRTA JAYA ABADI SINGARAJA," vol. 4, p. 9, 2015.

[5] H. Situmorang, "SISTEM PENDUKUNG KEPUTUSAN PEMILIHAN CALON PESERTA OLIMPIADE SAINS TINGKAT KABUPATEN LANGKAT PADA MADRASAH ALIYAH NEGERI (MAN) 2 TANJUNG PURA DENGANMENGGUNAKAN METODE SIMPLE ADDITIVE WEIGHTING (SAW)," no. 2, p. 7, 2015.

[6] I. Gunawan, A. Afrina, and C. Sofrawida, "SISTEM PENDUKUNG KEPUTUSAN PEMILIHAN KARYAWAN TERBAIK PADA LAMOIST LAYERS BATAM," JR, vol. 2, no. 2, Jan. 2019.

[7] L. Hakim, J. Nurjaman, and H. R. K. Tampangela, "SISTEM PENDUKUNG KEPUTUSAN PENENTUAN LOKASI PEMBUKAAN CABANG TOKO BARU MENGGUNAKAN METODE FUZZY - SAW,” vol. 2, no. 1, p. 7, 2018.

[8] E. Ismanto and N. Effendi, "Sistem Pendukung Keputusan Penerimaan Karyawan Dengan Metode Simple Additive Weighting (SAW)," SATIN, vol. 3, no. 1, p. 1, Jun. 2017.

[9] M. Fahmi and J. Sabtu, "SISTEM PENDUKUNG KEPUTUSAN UNTUK MENENTUKAN PENERIMA BEASISWA MENGGUNAKAN METODE SIMPLE ADDITIVE WEIGHTING (SAW)," vol. 2, no. 1, p. 9, 2018.

[10] A. B. Primahudi, F. A. Suciono, and A. A. Widodo, "SISTEM PENDUKUNG KEPUTUSAN UNTUK PEMILIHAN KARYAWAN DENGAN METODE SIMPLE ADDITIVE WEIGHTING DI PT. HERBA PENAWAR ALWAHIDA INDONESIA,” p. $24,2016$. 